\title{
Treatment of osteoarthritis with mesenchymal stem cells
}

\author{
WANG Wen \& CAO Wei* \\ Cellular Biomedicine Group, Palo Alto, CA 94301, USA
}

Received February 15, 2014; accepted April 3, 2014; published online May 20, 2014

\begin{abstract}
Osteoarthritis (OA) is one of the most prevalent joint diseases with prominent symptoms affecting the daily life of millions of middle aged and elderly people. Despite this, there are no successful medical interventions that can prevent the progressive destruction of OA joints. The onset of pathological changes in OA is associated with deviant activity of mesenchymal stem cells (MSCs), the multipotent precursors of connective tissue cells that reside in joints. Current therapies for OA have resulted in poor clinical outcomes without repairing the damaged cartilage. Intra-articular delivery of culture-expanded MSCs has opened new avenues of OA treatment. Pre-clinical and clinical trials demonstrated the feasibility, safety, and efficacy of MSC therapy. The Wnt/ $\beta$-catenin, bone morphogenetic protein 2, Indian hedgehog, and Mitogen-activated protein kinase signaling pathways have been demonstrated to be involved in OA and the mechanism of action of MSC therapies.
\end{abstract}

osteoarthritis, mesenchymal stem cells, intra-articular delivery

Citation: $\quad$ Wang W, Cao W. Treatment of osteoarthritis with mesenchymal stem cells. Sci China Life Sci, 2014, 57: 586-595, doi: 10.1007/s11427-014-4673-7

Osteoarthritis (OA) is the most common form of arthritis, a disease that can affect all the structures of the joints [1]. It was estimated in 2007 that more than 100 million people in China suffered from OA [2]. In adults, OA is the second leading cause of work disability, and the costs of OA have grown exponentially to astronomical figures over recent decades, accounting for up to $1 \%-2.5 \%$ of the gross national product of countries with aging populations, including the USA, Canada, the UK, France, and Australia [3]. OA is not only a process of erosion, but also describes an anomalous remodeling of joint tissues resulting from obesity, joint instability, or trauma [4]. The extensive pathologic changes in OA are identified as "joint failure", which includes degradation of the articular cartilage, osteosclerosis of the subchondral bone, retrogression of cruciate ligaments, hyperplasia of the synovium, degeneration of menisci, and hypertrophy of the joint capsule [5]. Many treatments have been advocated, but most resulted in dissatisfactory clinical re-

*Corresponding author (email: william.cao@cellbiomedgroup.com) sults without cartilage repair [6]. The only pharmacologic therapy for OA recommended by the American Academy of Orthopedic Surgeons (AAOS) is non-steroidal antiinflammatory drugs (NSAIDs) or tramadol for patients with symptomatic osteoarthritis. Intra-articular injection of hyaluronic acid is strongly not recommended [7]. In recent years, The New England Journal of Medicine published a series of results of controlled clinical trials showing little effect of arthroscopic surgery for the treatment of OA [8-11]. Furthermore, common treatments including physical therapy, viscosupplementation [12], glucosamine and/or chondroitin sulfate [13], and acupuncture [14] have demonstrated modest to no clinical benefit when compared with placebo. Moreover, all these treatments are generally intended to decrease pain, maintain or improve joint function, and minimize disability, not to regenerate joint tissue.

Cell therapy by surgical autologous chondrocyte implantation (ACI) has been used to regenerate chondral lesions for more than 20 years $[15,16]$, and clinical trials have confirmed the efficacy of ACI. However, clinical trials with 
contradictory outcomes have been published by different institutions when comparing ACI with other classical treatments, particularly microfracture. Knutsen et al. assessed 80 patients following either ACI or microfracture. At 24 months, both groups showed significant clinical improvement, and no significant differences were found between the methods in either histological quality of the regenerated tissue or clinical. However, microfracture was associated with better SF-36 physical component scores [17]. More recently, Saris et al. [18] evaluated the efficacy of microfracture and characterized chondrocyte implantation (CCI) in 118 patients. At 12 and 18 months, CCI demonstrated better structural repair as measured by histological evaluation. At the 36 month follow-up, CCI showed a significant improvement not only in the overall Knee injury and Osteoarthritis Outcome Score (KOOS), but also in the subchondral bone reaction [19]. Nonetheless, at the 5 year follow-up, although the clinical benefit was retained, the overall KOOS was not different between the CCI and microfracture groups [20]. Furthermore, ACI has several inherent disadvantages, such as chondrocyte dedifferentiation during culture that might result in fibrocartilage rather than hyaline cartilage formation [21], the two-stage surgical procedure may cause further cartilage damage and degeneration [22], and chondrocyte yields and their in vitro proliferative capacity decrease with age, especially in older patients [23]. Most importantly, ACI has been limited to focal cartilage defects caused by injury, while generalized cartilage loss in OA has been considered an exclusion criterion [15,16]. Recently, intra-articular injection of mesenchymal stem cells (MSCs) for the repair of joint surface lesions suggested the suitability of MSCs to replace autologous chondrocytes as the cell source for OA cartilage repair [24-26]. The advantages of intra-articular injection of MSCs for the treatment of OA include the simplicity and ease of MSC delivery, minimum invasiveness, and avoiding the potential disease transmission caused by the xenograft coverage used in ACI. In this review, we summarize the characterization of MSCs, differences between adipose-derived mesenchymal stem cells (A-MSCs) and bone marrow-derived mesenchymal stem cells (BM-MSCs), aberrant activity of MSCs in OA, preclinical and clinical data of MSC therapies for OA, and potential mechanisms of action, including the signaling pathways and tissue regeneration involved in the treatment of OA with MSCs.

\section{Mesenchymal stem cells and their phenotypes}

MSCs are precursors of connective tissue cells and were discovered by Alexander Friedenstein, who was the first to identify a group of fibroblast-like cells in the bone marrow of mice and guinea pigs with the capacity not only to differentiate into osteocytes, but also to form colonies from a single cell, referring to them as colony-forming units fibro- blastic (CFU-F) [27,28]. In 1991, Arnold Caplan suggested naming these cells 'mesenchymal stem cells' because they were capable of differentiation into all the cells of mesodermal lineage [29]. The minimum criteria for MSCs include plastic adherence and in vitro tri-lineage differentiation to adipogenic, chondrogenic, and osteogenic cells [30]. Additional requirements include cell surface expression of CD105, CD73, and CD90 and the absence of the hematopoietic markers CD45, CD19, CD79, CD11b, and HLA-DR. Nevertheless, the absence of a single specific marker that defines MSCs remains a particular challenge. Recently, a key potential marker for MSC enrichment, CD271 or low-affinity nerve growth factor receptor (LNGFR), was discovered [31]. After purification, $\mathrm{CD} 271^{+}$non-hematopoietic bone marrow cells appear to contain all the colony forming cells [32], and $\mathrm{CD} 271^{+}$cells demonstrate trilineage differentiation potential [31]. An additional marker, CD146 or melanoma cell adhesion molecule (MCAM), was also reported [32]. In human bone marrow, CD146 is expressed by a subpopulation of $\mathrm{CD} 271^{\text {bright }}$ cells, and the main subgroup in adults is $\mathrm{CD} 271^{\text {bright }} / \mathrm{CD} 146^{-}$cells, while the $\mathrm{CD} 271^{\text {bright }} / \mathrm{CD} 146^{+}$subgroup is dominant in pediatric and fetal bone marrow [33]. Both $\mathrm{CD} 271^{+} / \mathrm{CD} 146^{+}$and

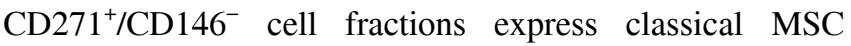
markers, including CD73, CD90, and CD105, and have tri-lineage differentiation potential. Furthermore, CD146 expression in vivo is localized to the perivascular regions within CD271-expression cells, while endosteal CD271 expressing cells lacked CD146 expression [32].

In addition to bone marrow, MSC populations can be isolated from dental pulp [34], umbilical cord blood [35], synovial membrane [36], adipose tissue [37], placenta [38], skin [39], umbilical cord perivascular cells [40], skeletal muscle [41], Wharton's jelly [42], meniscus [43], breast milk [44], cartilage [45], ligament [46], and fat pad [47]. The different sources of MSCs and their different phenotypic properties are shown in Table 1.

\section{Differences between adipose- and bone mar- row-derived MSCs}

Adipose tissue is both an energy reservoir and a complex endocrine organ containing adipose-derived mesenchymal stem cells (A-MSCs). A-MSCs were first described as adipocyte precursors by Frohlich in 1972 [48]. Further investigations demonstrated the stem cell-like plasticity of A-MSCs and their capacity to differentiate into cells of mesodermal origin, such as adipocyte, osteocyte, chondrocyte, and myocyte lineages [49]. A-MSCs are now considered an attractive source of MSCs because of the large numbers of cells that can be harvested with relatively little donor morbidity. Compared with BM-MSCs, A-MSCs are more easily cultured and grow more rapidly [50]. The main benefits of A-MSCs are that their proliferation and differen- 
Table 1 Characterization and phenotypic properties of MSCs from different sources

\begin{tabular}{|c|c|c|c|}
\hline Cells source & Character identification & Phenotype & Reference \\
\hline $\begin{array}{l}\text { Umbilical } \\
\text { cord blood }\end{array}$ & $\begin{array}{l}\text { Positive: CD13, CD29, CD49e, CD54, CD90 a-smooth muscle actin } \\
\text { Negative: CD14, CD31, CD34, CD 45, CD49d CD106 }\end{array}$ & $\begin{array}{l}\text { Rich in mesenchymal progenitors, similar to } \\
\text { haematopoietic progenitors. }\end{array}$ & $\begin{array}{l}\text { Erices et al. } \\
(2000)[35]\end{array}$ \\
\hline Dental pulp & $\begin{array}{l}\text { Positive: CD } 44, \text { CD29, CD106, a-smooth muscle actin } \\
\text { Negative: CD14, CD } 34, \text { CD } 45\end{array}$ & $\begin{array}{l}\text { Produces only sporadic, but densely calci- } \\
\text { fied, nodules, and does not form adipocytes. }\end{array}$ & $\begin{array}{l}\text { Gronthos et al. } \\
\text { (2000) [34] }\end{array}$ \\
\hline $\begin{array}{l}\text { Synovial } \\
\text { membrane }\end{array}$ & Positive: CD44, CD73, CD90, CD105, CD166, CD271 & $\begin{array}{l}\text { Stable, proliferative population with higher } \\
\text { chondrogenic potential. }\end{array}$ & $\begin{array}{l}\text { De Bari et al. } \\
\text { (2001) [36] }\end{array}$ \\
\hline $\begin{array}{l}\text { Adipose } \\
\text { tissue }\end{array}$ & $\begin{array}{l}\text { Positive: CD } 73 \text {, CD90, CD105 } \\
\text { Negative: CD31, CD34, CD } 45\end{array}$ & $\begin{array}{l}\text { Higher potential yields of MSCs with chon- } \\
\text { drogenic, adipogenic, ostseogenic, and myo- } \\
\text { genic potential. }\end{array}$ & $\begin{array}{l}\text { Zuk et al. } \\
(2001)[37]\end{array}$ \\
\hline Placenta & $\begin{array}{l}\text { Positive: CD90, CD105, CD166, CD49e, SH3, SH4, HLA-ABC } \\
\text { Negative: CD31, CD34, CD45, CD49d, CD123, HLA-DR }\end{array}$ & $\begin{array}{l}\text { Higher expansion potency compared to bone } \\
\text { marrow-derived MSCs. }\end{array}$ & $\begin{array}{l}\text { In't Anker et al. } \\
(2004)[38]\end{array}$ \\
\hline $\begin{array}{l}\text { Umbilical } \\
\text { cord peri- } \\
\text { vascular } \\
\text { cells }\end{array}$ & $\begin{array}{l}\text { Positive: CD105, CD73, CD90, CD44 } \\
\text { Negative: CD45, CD34, CD235a, CD106, CD123, SSEA-4, } \\
\text { HLA-DR, DP, DQ (MHC II), HLA-G, Oct4 }\end{array}$ & $\begin{array}{l}\text { Normal, rapidly expandable, } \mathrm{MHC}^{-/-} \text {cells } \\
\text { containing a subpopulation that exhibits a } \\
\text { functional osteogenic phenotype and elabo- } \\
\text { rated bone nodules. }\end{array}$ & $\begin{array}{l}\text { Sarugaser et al. } \\
(2005)[40]\end{array}$ \\
\hline Skin & $\begin{array}{l}\text { Positive: CD90, SH2, SH4, HLA I, CD44, CD49d, CD49e, CD49f, } \\
\text { CD166, CD105, EGFR, PDGFR } \\
\text { Negative: CD } 45, \text { CD38, CD34, CD31 }\end{array}$ & $\begin{array}{l}\text { Effectively differentiate into neuronal pre- } \\
\text { cursors better than bone marrow-derived } \\
\text { MSCs. }\end{array}$ & $\begin{array}{l}\text { Shih et al. } \\
(2005)[39]\end{array}$ \\
\hline $\begin{array}{l}\text { Skeletal } \\
\text { muscle }\end{array}$ & $\begin{array}{l}\text { Positive: NG2, CD146 } \\
\text { Negative: CD144, CD34, CD31 }\end{array}$ & $\begin{array}{l}\text { Strong myogenicity potential with typical } \\
\text { MSC surface marker patterns. }\end{array}$ & $\begin{array}{l}\text { Crisan et al. } \\
(2008)[41]\end{array}$ \\
\hline $\begin{array}{l}\text { Wharton's } \\
\text { jelly }\end{array}$ & $\begin{array}{l}\text { Positive: CD10, CD13, CD29, CD44, CD 90, CD105 } \\
\text { Negative: CD34, CD45, CD14, CD33, CD56, CD31, HLA-DR }\end{array}$ & $\begin{array}{l}\text { Greater expansion capability, faster growth in } \\
\text { vitro, and different cytokine secretome com- } \\
\text { pared to bone marrow MSCs. }\end{array}$ & $\begin{array}{l}\text { Troyer et al. } \\
\text { (2008) [42] }\end{array}$ \\
\hline Meniscus & $\begin{array}{l}\text { Positive: CD90, CD105, CD166, CD } 44 \\
\text { Negative: CD } 34, \text { CD } 45\end{array}$ & $\begin{array}{l}\text { Less activity compared to synovium or bone } \\
\text { marrow MSCs. }\end{array}$ & $\begin{array}{l}\text { Segawa et al. } \\
(2009)[43]\end{array}$ \\
\hline Cartilage & Positive: CD49e, Notch1, CD90, STRO-1 & $\begin{array}{l}\text { Higher fibronectin affinity and stronger col- } \\
\text { ony- forming efficiency. }\end{array}$ & $\begin{array}{l}\text { Williams et al. } \\
\text { (2010) }[45]\end{array}$ \\
\hline Breast milk & $\begin{array}{l}\text { Positive: CD44, CD29, SCA-1, SMA, vimentin, nestin } \\
\text { Negative: r CD33, CD34, CD 45, CD73 }\end{array}$ & $\begin{array}{l}\text { Normally proliferative, with chondrogenic, } \\
\text { osteogenic and adipogenic activity and nor- } \\
\text { mal MSCs phenotypes. }\end{array}$ & $\begin{array}{l}\text { Patki et al. } \\
(2010)[44]\end{array}$ \\
\hline Ligament & $\begin{array}{l}\text { Positive: CD29, CD44, CD49c, CD73, CD90, CD97, CD105, } \\
\text { CD146, and CD166 } \\
\text { Weekly positive: CD106, CD14 } \\
\text { Negative: CD11c, CD31, CD34, CD40, CD45, CD53, CD74, } \\
\text { CD133, CD144, CD163 }\end{array}$ & $\begin{array}{l}\text { Lower ability in chondrogenesis, osteogene- } \\
\text { sis and adipogenesis compared with bone } \\
\text { marrow MSCs. } \\
\text { Higher activity in ligamentogenesis. }\end{array}$ & $\begin{array}{l}\text { Steinert et al. } \\
(2011)[46]\end{array}$ \\
\hline
\end{tabular}

tiation potentials and telomerase are less affected by age than those of BM-MSCs [51].

A-MSCs and BM-MSCs have slightly different cell surface marker profiles. Most recently, characterization of canine A-MSCs and BM-MSCs identified that canine A-MSCs and BM-MSCs both demonstrated strong expression of CD29 and CD44, moderate expression of CD90, and were negative for CD34 and CD45. Oct3/4 and Sox 2 were equally expressed in canine A-MSCs and BM-MSCs, while Nanog expression was 2.5-fold higher in A-MSCs than in BM-MSCs [52]. Markers of human A-MSCs include STRO-1, CD146, and 3G5, in which the 3G5-positive fraction demonstrated the greatest enrichment for CFU-F compared with the other sorted cell populations [53]. However, there are slight differences in the cell surface phenotype profiles between A-MSCs and BM-MSCs despite sharing expression of key markers CD9, CD10, CD29, CD44, CD90, CD105, CD117, CD146, and STRO-1 [54]. Human A-MSCs express CD49d (VLA-4), which is not expressed by BM-MSCs, while A-MSCs lacked the expression of CD106 (VCAM-1), which was expressed by BM-MSCs [54]. This reciprocal expression is quite interesting because CD106 is the cognate receptor of CD49d. Moreover, only a small fraction of ex vivo expanded human BM-MSCs express STRO-1, while most human A-MSCs express it [55].

The differentiation potentials of A-MSCs and BM-MSCs are also slightly different. Compared with BM-MSCs, AMSCs have lower innate chondrogenesis, though high-dose combinations of growth factors (TGF $\beta 2$ and IGF-1) were capable of inducing comparable chondrogenesis in both cell types [56]. Recently, the impact of culture medium on the differentiation capacity of A-MSCs and BM-MSCs has been investigated. Human serum derivatives (thrombin-activated platelet-rich plasma or human platelet lysates) can lead to spontaneous osteogenesis in BM-MSCs and strong adipogenesis in A-MSCs expanded in vitro compared with fetal bovine serum-supplemented media [57,58].

The immunomodulative ability of MSCs is considered to be one of their most important properties. In response to inflammatory molecules such as interleukin-1 (IL-1), tumor necrosis factor-alpha (TNF- $\alpha$ ), and interferon-gamma (INF- $\gamma$ ), MSCs secrete a variety of growth factors and anti-inflammatory cytokines that feed back to many types of immune cell $[59,60]$. A-MSCs, like BM-MSCs, are negative for MHC class II molecules, CD80-B7, and CD40 [61-63]. By contrast, A-MSCs prohibit B cell proliferation, decrease 
immunoglobulin production, and restrict B cell functions more significantly than BM-MSCs [64].

\section{Atypical activity of MSCs in OA}

Although various investigations have demonstrated an atypical or defective activity of MSCs during OA progression, the relationship between this atypical activity of MSCs and OA progression itself remains unknown. Murphy et al. [65] revealed that bone marrow MSCs isolated from end-stage OA patients exhibit deficient proliferation and differentiation potentials compared with BM-MSCs from healthy, age-matched controls. In addition to a diminished yield and proliferative activity in OA MSCs, they also show a modified differentiation profile with decreased chondrogenesis and adipogenesis and increased osteogenesis. These aberrant activities in OA MSCs can be rescued by supplementation of the culture medium with growth factors such as epidermal growth factor or fibroblast growth factor 2 $[66,67]$. Human periosteal MSCs from donors younger than 30 years show spontaneous chondrogenesis in culture, while older donors do not exhibit spontaneous chondrogenesis [68]. Trabecular bone MSCs sorted on the basis of CD271 expression revealed that OA MSCs exhibit an age-related proliferation deficiency in vitro [69]. In OA patients, the number of MSCs in the synovial fluid compartment is much greater than in samples from healthy joints, and the number of cells increased with the severity of OA progression [70]. Synovial fluid MSCs show greater chondrogenic capability than MSCs separated from bone marrow [71].

\section{MSC therapy for OA}

Murphy et al. [24] were the first to propose the direct, intra- articular delivery of MSCs for the treatment of OA in a goat model. OA was induced by medial meniscectomy and anterior cruciate ligament transection (ACLT) for six weeks, and 10 million autologous BM-MSCs with sodium hyaluronan were injected. Twenty weeks after injection, the degeneration of articular cartilage, osteophyte formation, and subchondral bone thickening were reduced in the celltreated joints.

Since then, a great deal of attention has been focused on the intra-articular injection of expanded BM-MSCs on animal models of OA (Table 2). In a porcine cartilage defect model, seven million autologous BM-MSCs were injected into $8 \mathrm{~mm}$ long and $1 \mathrm{~mm}$ deep defects, and 6-12 weeks later, the cell-treated groups exhibited improved cartilage healing both histologically and morphologically, expressing the hyaline cartilage marker type II collagen [72]. In a rabbit model, OA was induced by ACLT for eight weeks and two million autologous BM-MSCs with a hyaluronan-based scaffold were delivered to the joint by intra-articular injection. Three to six months after surgery, the cartilage appeared significantly regenerative, expressing more type II collagen compared with the scaffold alone group. In addition, the cartilage matrix-degrading enzymes matrix metalloproteinase 1 and 3 (MMP-1, MMP-3) were decreased in the cell-treated group [73]. To track the injected MSCs, transgenic rats expressing dual luciferase (Luc) and LacZ were used in a rat massive meniscal defect model [74]. Twelve weeks after five million allogeneic Luc/LacZ ${ }^{+}$synovium-MSCs were injected, LacZ-positive regenerated menisci producing type II collagen were found, and the LacZ gene derived from MSCs was not found in any other organs except in synovium. In a spontaneous OA model in guinea pigs, seven million human commercial MSCs (Lonza, Basel, Switzerland) with hyaluronic acid (HA) were injected into the OA joint [75]. Five weeks after transplantation, partial cartilage regeneration with type II collagen expression was

Table 2 MSC-based treatment in pre-clinical experimental models of OA

\begin{tabular}{|c|c|c|c|c|c|c|}
\hline Animal model & $\begin{array}{l}\text { Animal } \\
\text { species }\end{array}$ & Cell source & Scaffold & Dose/cells & Outcome & Reference \\
\hline $\begin{array}{l}\text { ACLT+ meniscec- } \\
\text { tomy for } 6 \text { weeks }\end{array}$ & Goat & $\begin{array}{l}\text { Allogeneic bone } \\
\text { marrow }\end{array}$ & HA & $2 \times 10^{6}$ & $\begin{array}{l}\text { Degeneration of the articular cartilage, osteophytic } \\
\text { remodeling, and subchondral sclerosis were reduced in } \\
\text { cell-treated joints. }\end{array}$ & $\begin{array}{l}\text { Murphy et al. } \\
(2003)[24]\end{array}$ \\
\hline $\begin{array}{l}\text { Partial-thickness } \\
\text { cartilage defect } \\
\text { model }\end{array}$ & Porcine & $\begin{array}{l}\text { Autologous } \\
\text { bone marrow }\end{array}$ & HA & $9 \times 10^{5}$ & $\begin{array}{l}\text { At } 12 \text { weeks, the Wakitani scores showed marked } \\
\text { improvement in the quality of the repair tissue seen in } \\
\text { the MSC treated group. }\end{array}$ & $\begin{array}{l}\text { Lee et al. (2007) } \\
{[98]}\end{array}$ \\
\hline $\begin{array}{l}\text { Osteochondral } \\
\text { (full-thickness) } \\
\text { defect model }\end{array}$ & Rabbit & $\begin{array}{l}\text { Allogeneic } \\
\text { synovial }\end{array}$ & NA & $1 \times 10^{7}$ & $\begin{array}{l}\text { The histological score of the treated group was con- } \\
\text { sistently better at } 4,12 \text {, and } 24 \text { weeks than controls. } \\
\text { The MSC suspension promoted cartilage regeneration. }\end{array}$ & $\begin{array}{l}\text { Koga et al. } \\
(2008) \text { [99] }\end{array}$ \\
\hline $\begin{array}{l}\text { Osteochondral } \\
\text { defect model }\end{array}$ & Rabbit & $\begin{array}{l}\text { Allogeneic } \\
\text { bone marrow }\end{array}$ & $\begin{array}{l}\text { OPF/GMP } \\
+ \text { TGF- } \beta 1\end{array}$ & $1 \times 10^{7}$ & $\begin{array}{l}\text { Defects were filled with hyaline cartilage-like tissue } \\
\text { with zonal organization and intense glycosaminoglycan } \\
\text { staining. }\end{array}$ & $\begin{array}{l}\text { Guo et al. } \\
(2010)[100]\end{array}$ \\
\hline $\begin{array}{l}7 \text { months old, } \\
\text { spontaneous OA }\end{array}$ & $\begin{array}{l}\text { Guinea } \\
\text { pig }\end{array}$ & $\begin{array}{l}\text { Commercial } \\
\text { human MSC }\end{array}$ & HA & $7 \times 10^{6}$ & $\begin{array}{l}\text { At } 5 \text { weeks post transplantation, partial cartilage repair } \\
\text { was noted in the HA-MSC group with type II collagen } \\
\text { around both residual chondrocytes and transplanted } \\
\text { MSCs in the OA cartilage. }\end{array}$ & $\begin{array}{l}\text { Sato et al. } \\
(2012) \text { [75] }\end{array}$ \\
\hline
\end{tabular}


noted in the cell-treated group.

These successful preclinical studies led to the initiation of many clinical trials (Table 3). The majority of these reports involved the use of autologous, culture-expanded BM-MSCs or A-MSCs. Notably, the majority of technical approaches used intra-articular injection to deliver the MSCs to the synovial fluid compartment using a hyaluronan scaffold, which is a major component of synovial fluid. The clinical reports listed in Table 3 tested cell injection doses from one to one hundred million cells in a single injection.

In a prospective, randomized, controlled clinical trial with two years follow-up, the microfracture with autologous BM-MSCs treatment group (28 patients) achieved significant improvements in the Tegner Lysholm and International Knee Documentation Committee (IKDC) scores. Magnetic resonance imaging (MRI) scans performed one year after the surgical intervention showed significantly better Magnetic Resonance Observation of Cartilage Repair Tissue (MOCART) scores for the cell-recipient group than the microfracture alone group (28 patients) [76]. In a pilot study of $12 \mathrm{OA}$ patients with intra-articular injection of 40 million autologous expanded BM-MSCs, the patients showed a large improvement in algofunctional indices by one year, and MRI scanning exhibited a $27 \%$ decrease in poor cartilage areas with improvement of cartilage quality in 11 of the
12 patients [77]. Most recently, two clinical trials have attracted a lot of interest. In an Osiris Therapeutics Inc. funded, randomized, double-blinded, controlled clinical trial [25], 55 patients at seven institutions experienced a partial medial meniscectomy followed by injection with (5$15) \times 10^{7}$ allogeneic BM-MSCs and/or sodium hyaluronate as a vehicle control. At the two year follow-up, the meniscal volume achieved a $15 \%$ threshold in $24 \%$ of patients determined by quantitative MRI, indicating evidence of meniscus regeneration after treatment with allogeneic human BMMSCs. Another intriguing proof-of-concept clinical trial in which patients with OA were treated with $(1-10) \times 10^{7}$ autologous A-MSCs also demonstrated improved Western Ontario and McMaster Universities Osteoarthritis Index (WOMAC) scores at six months after injection in the $10 \times 10^{7}$ dose group [26]. Most importantly, the arthroscopy and histological assessments showed substantial thick, hyaline-like cartilage regeneration, suggesting that the intra-articular injection of A-MSCs regenerated hyaline-like articular cartilage without causing adverse events. All of these pre-clinical investigations and clinical trials demonstrated that the intra-articular injection of MSCs into an OA joint was not associated with apparent adverse events, but instead showed improved function, reduced pain, and regenerated hyaline-like cartilage in the affected joint.

Table 3 Clinical trials of MSC treatment for OA

\begin{tabular}{|c|c|c|c|c|c|}
\hline Indications & Cell source & Dose/cells & Study design & Outcome & Reference \\
\hline $\begin{array}{l}1 \text { patient with } \\
\text { degenerative } \\
\text { joint disease }\end{array}$ & $\begin{array}{l}\text { Autologous } \\
\text { bone marrow }\end{array}$ & NA & $\begin{array}{l}24 \text { weeks follow-up visit after intra-articular } \\
\text { injection }\end{array}$ & $\begin{array}{l}\text { The patient had statistically significant carti- } \\
\text { lage and meniscus growth by MRI, as well as } \\
\text { increased range of motion and decreased } \\
\text { modified VAS pain scores. }\end{array}$ & $\begin{array}{l}\text { Centeno } \\
\text { et al. }(2008) \\
{[101]}\end{array}$ \\
\hline $\begin{array}{l}50 \text { patients } \\
\text { with mild to } \\
\text { moderate } \\
\text { knee OA }\end{array}$ & $\begin{array}{l}\text { Autologous } \\
\text { cells }\end{array}$ & NA & $\begin{array}{l}\text { Received MSC concentrate injection along } \\
\text { with the arthroscopic debridement }\end{array}$ & $\begin{array}{l}\text { The overall osteoarthritis outcome score, } \\
\text { especially the quality of life, was improved. }\end{array}$ & $\begin{array}{l}\text { Varma et al. } \\
(2010)[102]\end{array}$ \\
\hline $\begin{array}{l}4 \text { patients } \\
\text { with moderate } \\
\text { to severe } \\
\text { knee OA }\end{array}$ & $\begin{array}{l}\text { Autologous } \\
\text { bone marrow }\end{array}$ & $(8-9) \times 10^{6}$ & Intra-articular injection of cultured MSCs & $\begin{array}{l}\text { The walking time and pain improved for } 3 \\
\text { patients, and } 1 \text { patient remained unchanged. }\end{array}$ & $\begin{array}{l}\text { Davatchi } \\
\text { et al. }(2011) \\
{[103]}\end{array}$ \\
\hline $\begin{array}{l}12 \text { patients } \\
\text { with knee OA }\end{array}$ & $\begin{array}{l}\text { Autologous } \\
\text { infra-patellar } \\
\text { fat pad }\end{array}$ & $1.89 \times 10^{6}$ & $\begin{array}{l}\text { Intra-articular injection of cultured MSCs with } \\
\text { PRP }\end{array}$ & $\begin{array}{l}\text { The mean Lysholm score, Tegner activity } \\
\text { scale, and VAS scores of patients in the } \\
\text { study group improved significantly. }\end{array}$ & $\begin{array}{l}\text { Koh et al. } \\
(2012)[104]\end{array}$ \\
\hline $\begin{array}{l}56 \text { patients } \\
\text { with unicom- } \\
\text { partmental } \\
\text { knee OA }\end{array}$ & $\begin{array}{l}\text { Autologous } \\
\text { bone marrow }\end{array}$ & $1.5 \times 10^{7}$ & $\begin{array}{l}\text { Intra-articular injection of cultured MSCs with } \\
\text { hyaluronic acid } 3 \text { weeks after HTO and mi- } \\
\text { crofracture }\end{array}$ & $\begin{array}{l}\text { The treatment was effective in improving } \\
\text { both short-term clinical and MOCART out- } \\
\text { comes. }\end{array}$ & $\begin{array}{l}\text { Wong et al. } \\
(2013)[76]\end{array}$ \\
\hline $\begin{array}{l}12 \text { patients } \\
\text { with chronic } \\
\text { knee pain }\end{array}$ & $\begin{array}{l}\text { Autologous } \\
\text { bone marrow }\end{array}$ & $4 \times 10^{7}$ & $\begin{array}{l}1 \text { year follow-up visit after intra-articular } \\
\text { injection }\end{array}$ & $\begin{array}{l}\text { Patients exhibited rapid and progressive } \\
\text { improvement of algofunctional indices that } \\
\text { approached } 65 \% \text { to } 78 \% \text { after } 1 \text { year. }\end{array}$ & $\begin{array}{l}\text { Orozco et al. } \\
(2013)[77]\end{array}$ \\
\hline $\begin{array}{l}18 \text { patients } \\
\text { with knee OA }\end{array}$ & $\begin{array}{l}\text { Autologous } \\
\text { adipose }\end{array}$ & $(1-10) \times 10^{7}$ & $\begin{array}{l}\text { The phase I study consisted of intra-articular } \\
\text { injection of } 3 \text { dose-escalation cohorts. The } \\
\text { phase II study included } 9 \text { patients receiving } \\
\text { the high-dose and their } 6 \text { months follow-up } \\
\text { visit }\end{array}$ & $\begin{array}{l}\text { Intra-articular injection of the high dose } \\
\text { improved function and pain of the knee joint } \\
\text { without causing adverse events, and reduced } \\
\text { cartilage defects by regeneration of hya- } \\
\text { line-like articular cartilage. }\end{array}$ & $\begin{array}{l}\text { Jo et al. } \\
\text { (2014) [26] }\end{array}$ \\
\hline $\begin{array}{l}55 \text { patients } \\
\text { with partial } \\
\text { medial me- } \\
\text { niscectomy }\end{array}$ & $\begin{array}{l}\text { Allogeneic } \\
\text { bone marrow }\end{array}$ & $5 \times 10^{7}$ & $\begin{array}{l}\text { A single superolateral knee injection of cul- } \\
\text { tured MSCs } 7 \text { to } 10 \text { days after the meniscec- } \\
\text { tomy }\end{array}$ & $\begin{array}{l}\text { Treated patients had a significant reduction } \\
\text { in pain, along with significantly increased } \\
\text { meniscal volume. }\end{array}$ & $\begin{array}{l}\text { Vangsness } \\
\text { et al. (2014) } \\
{[25]}\end{array}$ \\
\hline
\end{tabular}




\section{Potential mechanisms involved in $\mathrm{OA}$ pro- gression and MSC treatment}

In OA joints, the synovium appears to have at least two crucial roles in the development and progression of OA. On one hand, synovium might be the target of effective repair responses involving endogenous MSCs. On the other hand, the resident cell population within the synovium affects the homeostasis of the joint, and can initiate degenerative changes in OA $[78,79]$. The infiltration of $\mathrm{CD}^{+} \mathrm{T}$ cells and $\mathrm{CD} 8^{+}$macrophages is essentially increased in the synovium during early-stage compared with late-stage OA [80]. Moreover, cytokines, including interleukin-1 beta (IL-1 $\beta$ ) and TNF- $\alpha$, and chemokines (CCL 19 and monocyte chemotactic protein 1) may be released from the synovium, stimulating articular chondrocytes by activating various cell surface receptors, including Toll-like receptors (TLRs), and thereby promoting cartilage catabolism and inhibiting matrix synthesis [81]. All these data suggest that synovial inflammation is a feature in the early-stages of OA and might initiate the degenerative cascades that result in tissue destruction.

Chondrocytes also play an important role in OA progression via several signaling pathways. Chondrocytes can be activated through the nuclear factor kappa B (NF$\kappa \mathrm{B})$, stress-induced, and mitogen-activated protein kinase (MAPK) pathways by mechanical and inflammatory stimuli to express cytokine and chemokine receptors, MMPs, cyclooxygenase 2 (COX-2), and IL-1 [82]. Cartilage matrix-degrading enzymes secreted by chondrocytes and synovial cells include aggrecanases and collagenases. Matrix degradation during early-stage OA may be caused by aggrecanases, MMP-3, and a disintegrin and metalloproteinase with thrombospondin motifs 5 (ADAMTS-5) activities, followed by increased activity of collagenase MMP-13, which is highly efficient at degrading type II collagen [83]. These results were confirmed in global knockout Adamts $-5^{-/-}$mice, which exhibited protection against OA progression and in global knockout $M m p-13^{-/-}$mice, which showed inhibition of cartilage erosion $[84,85]$. Recently, the canonical $\mathrm{Wnt} / \beta$-catenin signaling pathway was suggested to have dual effects on cartilage destruction during OA progression. A global knockout $F r z b^{-/}$, a Wnt antagonist, exhibited greater cartilage loss than wild type controls, and the increased cartilage damage was associated with increased levels of $\beta$-catenin-dependent Wnt signaling and matrix metalloproteinase 3 [86]. Another experiment also found that Wnt antagonist $D k k-1$ chondrocyte-specific transgenic mice, Col2 $\alpha 1-D k k 1$, had significantly mitigated surgeryinduced OA because of decreased Mmpl3 and Adamts 4 expression compared with their wild-type littermates, while Wnt-3a, an agonist of Wnt, induced Mmpl3 and Adamts 4 expression in chondrocytes in primary culture [87]. However, further investigation found that Wnt-3a could block IL-1 $\beta$-induced MMP-1 and MMP-13 expression, while co-incubation with Dkk-1 increased IL-1 $\beta$-induced expression of MMPs. This indicates a negative feedback loop wherein Wnt/ $\beta$-catenin signaling in human chondrocytes played an anti-catabolic role by preventing MMP expression induced by IL-1 $\beta$ [88]. Another investigation also found that SOST, a potent inhibitor of canonic Wnt signaling that binds to Wnt receptor Low-density-lipoprotein receptor-related protein 5/6 (LRP5/6), inhibited further degradation of OA cartilage [89]. More recently, bone morphogenetic protein 2 (BMP-2) signaling was found to increase $\beta$-catenin nuclear translocation, LRP-5 expression, MMP levels (MMP-9, MMP-13, and MMP 14), ADAMTS5, and collagen X expression. The BMP-2-induced LRP-5 up-regulation was mediated by $\mathrm{Smad} 1 / 5 / 8$ binding on the LRP-5 promoter, which contributed to the hypertrophy of OA chondrocytes via crosstalk with canonical Wnt/ $\beta$ catenin signaling [90].

Whether subchondral bone thickening precedes fibrillation of the cartilage or not remains controversial. Recently, articular chondrocytes isolated from normal joints were found to prohibit normal subchondral bone osteoblastogenesis, whereas chondrocytes isolated from OA joints strengthened subchondral bone osteoblastogenesis by significantly activating ERK 1/2 phosphorylation in co-culture, indicating that OA chondrocytes may alter subchondral bone osteoblastogenesis via the MAPK signaling pathways [91]. Interestingly, OA subchondral bone osteoblasts were also able to increase articular chondrocyte differentiation by inhibiting p38 phosphorylation and inducing ERK $1 / 2$ phosphorylation [92].

In terms of the mechanism of action of MSC therapy for $\mathrm{OA}$, a recent investigation found that injection of human MSCs promoted rat meniscal regeneration by expressing rat collagen II, whereas a hedgehog antagonist prohibited, and a hedgehog agonist promoted rat collagen II expression. These data suggest that intra-articular injection of hMSCs repaired cartilage by activating the Indian hedgehog signaling pathway [93]. The expression of Notch-1 was also found in MSCs from healthy and OA articular cartilage, but the numbers of Notch-1-positive MSCs were much larger when isolated from $\mathrm{OA}$ articular cartilage than healthy samples [94], indicating that Notch signaling is overexpressed during OA progression and that intra-articular therapy with normal MSCs down-regulates the Notch signaling pathway. The transient receptor potential vanilloid 4 (TRPV 4) ion channel, a $\mathrm{Ca}^{2+}$-preferred cation channel, was also found to play an important role in the progression of OA in mice using a global Trpv4 knock out [95]. Further investigations have demonstrated that BM-MSCs from Trpv $4^{-/-}$ mice showed decreased adipogenesis and osteogenesis 
phenotypes, whereas A-MSCs from Trp $v 4^{-1-}$ mice exhibited increased adipogenesis and osteogenesis and decreased chondrogenesis compared with those in wild type controls, indicating that Trpv4 plays a chondroprotective role during OA progression [96]. Recent investigations found that in OA animal models, intra-articular injection of MSCs decreased articular cartilage erosion, probably by inhibiting MMP-13, TNF- $\alpha$, and IL-1 $\beta$ expression [75,97]. Because MMP-13, TNF- $\alpha$, and IL-1 $\beta$ expressions were associated with $\mathrm{Wnt} / \beta$-catenin, MAPK, and BMP signaling based on the studies mentioned above, we inferred that these signals may also be involved in the effects of MSC treatment on OA (Figure 1).

\section{Conclusion}

In conclusion, $\mathrm{OA}$ is a disease characterized by progressive and irreversible destruction of the entire joint structure. OA seems to occur because of changes in the quantity, phenotype, and differentiation potential of resident mesenchymal cells. Nevertheless, current therapies, including conservative treatments and surgery, result in poor clinical outcomes with no cartilage repair. Successful pre-clinical results using intra-articular injection of MSCs provide the impetus for considering injection of MSCs as a useful therapy for this obstinate disease. Recent clinical studies have demonstrated exciting results with hyaline-like cartilage regeneration accompanied by pain relief, joint function improvement, and amelioration of the joint's health condition. Several signaling pathways have been found to be altered, along with changes in the functions, of joint-resident MSCs during OA progression, suggesting the necessity of exogenous MSC transplantation.

However, there are still a large number of unanswered questions, some of which are exigent. For example, does MSC treatment repair the cartilage degradation, synovitis, and subchondral bone sclerosis directly or through paracrine effects? Which factors released by MSCs protect cartilage from degradation or trigger regeneration or repair of cartilage? What are the mechanisms of the cross-talk and feedback between injected MSCs and synovium, articular cartilage, and subchondral bone, and which are relevant to directing disease progression and remission? Answering these questions will most likely require systemic approaches that apply molecular level genomics, epigenetics, proteomics, and metabolomics to investigate the mechanisms of action of MSCs during OA treatment.

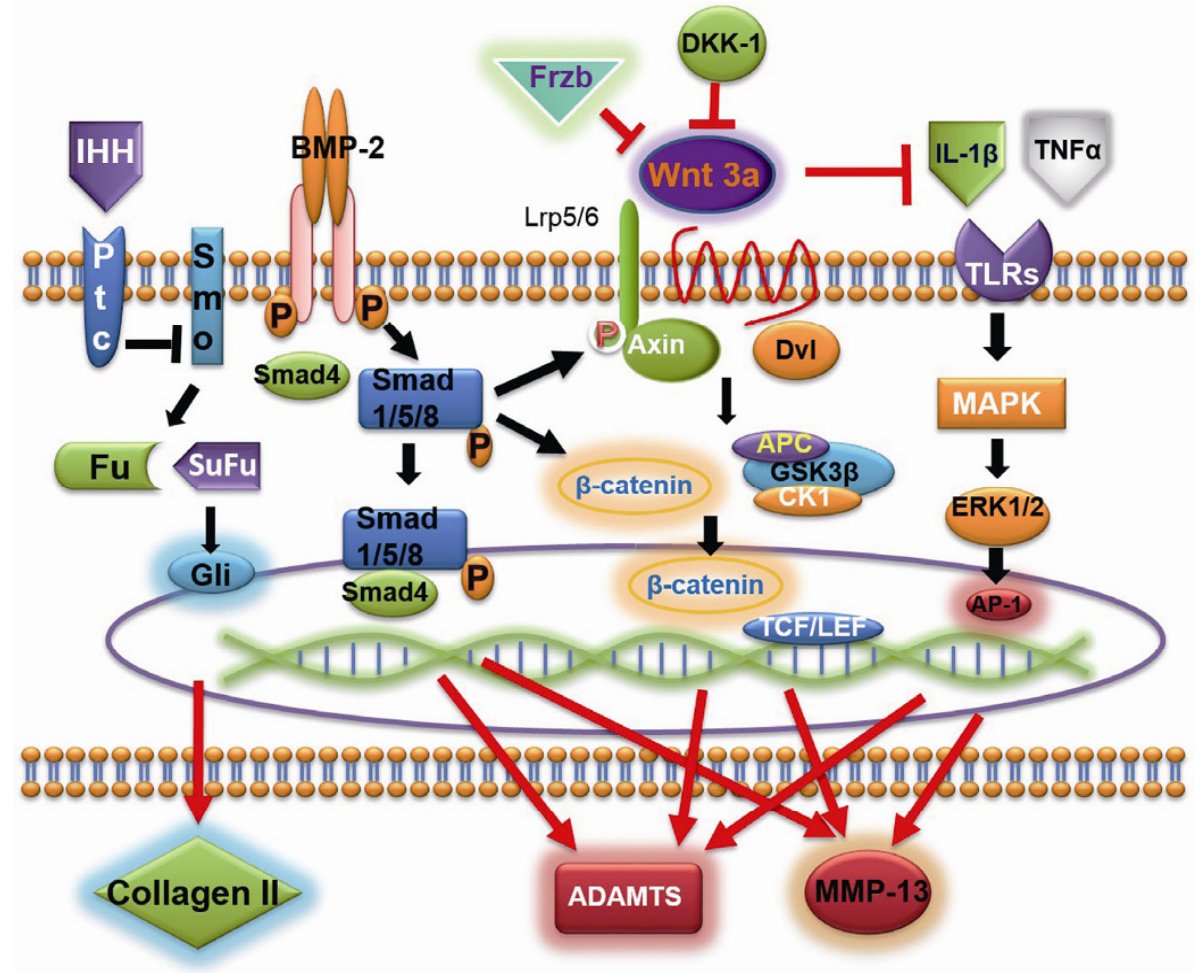

Figure 1 Potential mechanisms involved in OA progression and MSC treatment. Intra-articular injection of hMSCs promotes rat meniscal regeneration by expression of rat collagen II via Indian Hedgehog (IHH) signaling, whereas Smoothened IHH antagonist cyclopamine prohibited, and Smoothened IHH agonist SAG promoted, rat collagen II expression. BMP-2 signaling may not only increase MMP levels directly, but also increase $\beta$-catenin translocation via crosstalk with canonical Wnt/ $\beta$-catenin signaling. Wnt-3a, an agonist of Wnt, may induce MMP13 and ADAMTS-4 expression, while $F r z b^{-/-}$mice exhibited cartilage loss and Dkkl transgenics showed cartilage gain, though both were Wnt antagonists. MAPK signaling may also activate chondrocytes to secrete ADAMTS and MMPs. 
1 Centers for Disease Control and Prevention. Prevalence of doctor-diagnosed arthritis and arthritis-attributable activity limitationUnited States, 2010-2012. MMWR Morb Mortal Wkly Rep, 2013, 62: 869-873

2 Deng LF, Yang QM. Osteoarthritis. J Chin Med, 2007, 42: 76-78

3 Ethgen O, Kahler KH, Kong SX, Reginster JY, Wolfe F. The effect of health related quality of life on reported use of health care resources in patients with osteoarthritis and rheumatoid arthritis: a longitudinal analysis. J Rheumatol, 2002, 29: 1147-1155

4 Blagojevic M, Jinks C, Jeffery A, Jordan KP. Risk factors for onset of osteoarthritis of the knee in older adults: a systematic review and meta-analysis. Osteoarthr Cartilage, 2010, 18: 24-33

5 Loeser RF, Goldring SR, Scanzello CR, Goldring MB. Osteoarthritis: a disease of the joint as an organ. Arthritis Rheum, 2012, 64: 1697-1707

6 Hawker G, Mendel A, Lam MA, Akhavan PS, Cancino-Romero J, Waugh E, Jamal S, Mian S, Jaglal S. A clinical decision rule to enhance targeted bone mineral density testing in healthy mid-life women. Osteoporos Int, 2012, 23: 1931-1938

7 Brown GA. AAOS clinical practice guideline: treatment of osteoarthritis of the knee: evidence-based guideline, 2nd edition. J Am Acad Orthop Surg, 2013, 21: 577-579

8 Katz JN, Losina E. Surgery versus physical therapy for meniscal tear and osteoarthritis. N Engl J Med, 2013, 369: 677-678

9 Kirkley A, Birmingham TB, Litchfield RB, Giffin JR, Willits KR, Wong CJ, Feagan BG, Donner A, Griffin SH, D'Ascanio LM, Pope JE, Fowler PJ. A randomized trial of arthroscopic surgery for osteoarthritis of the knee. N Engl J Med, 2008, 359: 1097-1107

10 Sihvonen R, Paavola M, Malmivaara A, Itälä A, Joukainen A, Nurmi H, Kalske J, Järvinen T L, Finnish Degenerative Meniscal Lesion Study (FIDELITY) Group. Arthroscopic partial meniscectomy versus sham surgery for a degenerative meniscal tear. N Engl J Med, 2013, 369: 2515-2524

11 Moseley JB, O’Malley K, Petersen NJ, Menke TJ, Brody BA, Kuykendall DH, Hollingsworth JC, Ashton CM, Wray NP. A controlled trial of arthroscopic surgery for osteoarthritis of the knee. N Engl J Med, 2002, 347: 81-88

12 Rutjes AW, Juni P, da Costa BR, Trelle S, Nüesch E, Reichenbach S. Viscosupplementation for osteoarthritis of the knee: a systematic review and meta-analysis. Ann Intern Med, 2012, 157: 180-191

13 Sawitzke AD, Shi H, Finco MF, Harris CL, Singer NG, Bradley JD, Silver D, Jackson CG, Lane NE, Oddis CV, Wolfe F, Lisse J, Furst DE, Bingham CO, Reda DJ, Moskowitz RW, Williams HJ, Clegg DO. Clinical efficacy and safety of glucosamine, chondroitin sulphate, their combination, celecoxib or placebo taken to treat osteoarthritis of the knee: 2-year results from gait. Ann Rheum Dis, 2010, 69: 1459-1464

14 Witt C, Brinkhaus B, Jena S, Linde K, Streng A, Wagenpfeil S, Hummelsberger J, Walther H U, Melchart D, Willich SN. Acupuncture in patients with osteoarthritis of the knee: a randomised trial. Lancet, 2005, 366: 136-143

15 Brittberg M, Lindahl A, Nilsson A, Ohlsson C, Isaksson O, Peterson L. Treatment of deep cartilage defects in the knee with autologous chondrocyte transplantation. N Engl J Med, 1994, 331: 889-895

16 Brittberg M, Faxen E, Peterson L. Carbon fiber scaffolds in the treatment of early knee osteoarthritis. A prospective 4-year followup of 37 patients. Clin Orthop Relat Res, 1994, 155-164

17 Knutsen G, Engebretsen L, Ludvigsen TC, Drogset JO, Grøntvedt T, Solheim E, Strand T, Roberts S, Isaksen V, Johansen O. Autologous chondrocyte implantation compared with microfracture in the knee. A randomized trial. J Bone Joint Surg Am, 2004, 86-A: 455-464

18 Saris DB, Vanlauwe J, Victor J, Haspl M, Bohnsack M, Fortems Y, Vandekerckhove B, Almqvist KF, Claes T, Handelberg F, Lagae K, van der Bauwhede J, Vandenneucker H, Yang K G, Jelic M, Verdonk R, Veulemans N, Bellemans J, Luyten FP. Characterized chondrocyte implantation results in better structural repair when treating symptomatic cartilage defects of the knee in a randomized controlled trial versus microfracture. Am J Sports Med, 2008, 36: 235-246

19 Saris DB, Vanlauwe J, Victor J, Almqvist KF, Verdonk R, Bellemans
J, Luyten FP, TIG/ACT/01/2000\&EXT Study Group. Treatment of symptomatic cartilage defects of the knee: characterized chondrocyte implantation results in better clinical outcome at 36 months in a randomized trial compared to microfracture. Am J Sports Med, 2009, 37(Suppl 1): 10S-19S

20 Vanlauwe J, Saris DB, Victor J, Almqvist KF, Bellemans J, Luyten FP, TIG/ACT/01/2000\&EXT Study Group. Five-year outcome of characterized chondrocyte implantation versus microfracture for symptomatic cartilage defects of the knee: early treatment matters. Am J Sports Med, 2011, 39: 2566-2574

21 von der Mark K, Gauss V, von der Mark H, Müller P. Relationship between cell shape and type of collagen synthesised as chondrocytes lose their cartilage phenotype in culture. Nature, 1977, 267: 531-532

22 Knutsen G, Drogset JO, Engebretsen L, Grøntvedt T, Isaksen V, Ludvigsen TC, Roberts S, Solheim E, Strand T, Johansen O. A randomized trial comparing autologous chondrocyte implantation with microfracture. Findings at five years. J Bone Joint Surg Am, 2007, 89: 2105-2112

23 Barbero A, Grogan S, Schäfer D, Heberer M, Mainil-Varlet P, Martin I. Age related changes in human articular chondrocyte yield, proliferation and post-expansion chondrogenic capacity. Osteoarthr Cartilage, 2004, 12: 476-484

24 Murphy JM, Fink DJ, Hunziker EB, Barry FP. Stem cell therapy in a caprine model of osteoarthritis. Arthritis Rheum, 2003, 48: 3464-3474

25 Vangsness CT Jr., Farr J 2nd, Boyd J, Dellaero DT, Mills CR, LeRoux-Williams M. Adult human mesenchymal stem cells delivered via intra-articular injection to the knee following partial medial meniscectomy: a randomized, double-blind, controlled study. J Bone Joint Surg Am, 2014, 96: 90-98

26 Jo CH, Lee YG, Shin WH, Kim H, Chai JW, Jeong EC, Kim JE, Shim H, Shin JS, Shin IS, Ra JC, Oh S, Yoon KS. Intra-articular injection of mesenchymal stem cells for the treatment of osteoarthritis of the knee: a proof-of-concept clinical trial. Stem Cells, 2014, 32: 1254-1266

27 Friedenstein AJ, Piatetzky S II, Petrakova KV. Osteogenesis in transplants of bone marrow cells. J Embryol Exp Morphol, 1966, 16: 381-390

28 Friedenstein AJ, Chailakhjan RK, Lalykina KS. The development of fibroblast colonies in monolayer cultures of guinea-pig bone marrow and spleen cells. Cell Tissue Kinet, 1970, 3: 393-403

29 Caplan AI. Mesenchymal stem cells. J Orthop Res, 1991, 9: 641-650

30 Dominici M, Le Blanc K, Mueller I, Slaper-Cortenbach I, Marini F, Krause D, Deans R, Keating A, Prockop Dj, Horwitz E. Minimal criteria for defining multipotent mesenchymal stromal cells. The international society for cellular therapy position statement. Cytotherapy, 2006, 8: 315-317

31 Jones EA, Kinsey SE, English A, Jones RA, Straszynski L, Meredith DM, Markham AF, Jack A, Emery P, McGonagle D. Isolation and characterization of bone marrow multipotential mesenchymal progenitor cells. Arthritis Rheum, 2002, 46: 3349-3360

32 Tormin A, Li O, Brune JC, Walsh S, Schütz B, Ehinger M, Ditzel N, Kassem M, Scheding S. Cd146 expression on primary nonhematopoietic bone marrow stem cells is correlated with in situ localization. Blood, 2011, 117: 5067-5077

33 Maijenburg MW, Kleijer M, Vermeul K, Mul EP, van Alphen FP, van der Schoot CE, Voermans C. The composition of the mesenchymal stromal cell compartment in human bone marrow changes during development and aging. Haematologica, 2012, 97: 179-183

34 Gronthos S, Mankani M, Brahim J, Robey PG, Shi S. Postnatal human dental pulp stem cells (dpscs) in vitro and in vivo. Proc Natl Acad Sci USA, 2000, 97: 13625-13630

35 Erices A, Conget P, Minguell JJ. Mesenchymal progenitor cells in human umbilical cord blood. Br J Haematol, 2000, 109: 235-242

36 De Bari C, Dell'Accio F, Tylzanowski P, Luyten FP. Multipotent mesenchymal stem cells from adult human synovial membrane. Arthritis Rheum, 2001, 44: 1928-1942

37 Zuk PA, Zhu M, Mizuno H, Huang J, Futrell JW, Katz AJ, Benhaim P, Lorenz HP, Hedrick MH. Multilineage cells from human adipose 
tissue: Implications for cell-based therapies. Tissue Eng, 2001, 7: 211-228

38 In't Anker PS, Scherjon SA, Kleijburg-van der Keur C, de Groot-Swings GM, Claas FH, Fibbe WE, Kanhai HH. Isolation of mesenchymal stem cells of fetal or maternal origin from human placenta. Stem Cells, 2004, 22: 1338-1345

39 Shih DT, Lee DC, Chen SC, Tsai RY, Huang CT, Tsai CC, Shen EY, Chiu WT. Isolation and characterization of neurogenic mesenchymal stem cells in human scalp tissue. Stem Cells, 2005, 23: 1012-1020

40 Sarugaser R, Lickorish D, Baksh D, Hosseini MM, Davies JE. Human umbilical cord perivascular (HUCPV) cells: a source of mesenchymal progenitors. Stem cells, 2005, 23: 220-229

41 Crisan M, Yap S, Casteilla L, Chen CW, Corselli M, Park TS, Andriolo G, Sun B, Zheng B, Zhang L, Norotte C, Teng PN, Traas J, Schugar R, Deasy BM, Badylak S, Buhring HJ, Giacobino JP, Lazzari L, Huard J, Péault B. A perivascular origin for mesenchymal stem cells in multiple human organs. Cell Stem Tell, 2008, 3: 301-313

42 Troyer DL, Weiss ML. Concise review: Wharton's jelly-derived cells are a primitive stromal cell population. Stem Cells, 2008, 26: 591-599

43 Segawa Y, Muneta T, Makino H, Nimura A, Mochizuki T, Ju YJ, Ezura Y, Umezawa A, Sekiya I. Mesenchymal stem cells derived from synovium, meniscus, anterior cruciate ligament, and articular chondrocytes share similar gene expression profiles. J Orthop Res, 2009, 27: 435-441

44 Patki S, Kadam S, Chandra V, Bhonde R. Human breast milk is a rich source of multipotent mesenchymal stem cells. Human cell, 2010, 23: $35-40$

45 Williams R, Khan IM, Richardson K, Nelson L, McCarthy HE, Analbelsi T, Singhrao SK, Dowthwaite GP, Jones RE, Baird DM, Lewis H, Roberts S, Shaw HM, Dudhia J, Fairclough J, Briggs T, Archer CW. Identification and clonal characterisation of a progenitor cell sub-population in normal human articular cartilage. PLoS ONE, 2010, 5: e13246

46 Steinert AF, Kunz M, Prager P, Barthel T, Jakob F, Nöth U, Murray MM, Evans CH, Porter RM. Mesenchymal stem cell characteristics of human anterior cruciate ligament outgrowth cells. Tissue Eng Part A, 2011, 17: 1375-1388

47 Khan WS, Adesida AB, Tew SR, Longo UG, Hardingham TE. Fat pad-derived mesenchymal stem cells as a potential source for cell-based adipose tissue repair strategies. Cell Prolif, 2012, 45: 111-120

48 Frohlich J, Vost A, Hollenberg $\mathrm{CH}$. Organ culture of rat white adipose tissue. Biochim Biophys Acta, 1972, 280: 579-587

49 Zuk PA. Stem cell research has only just begun. Science, 2001, 293: 211-212

50 Lindroos B, Suuronen R, Miettinen S. The potential of adipose stem cells in regenerative medicine. Stem Cell Rev, 2011, 7: 269-291

51 Mirsaidi A, Kleinhans KN, Rimann M, Tiaden AN, Stauber M, Rudolph KL, Richards PJ. Telomere length, telomerase activity and osteogenic differentiation are maintained in adipose-derived stromal cells from senile osteoporotic samp6 mice. J Tissue Eng Regen Med, 2012, 6: 378-390

52 Takemitsu H, Zhao D, Yamamoto I, Harada Y, Michishita M, Arai T. Comparison of bone marrow and adipose tissue-derived canine mesenchymal stem cells. BMC Vet Res, 2012, 8: 150

53 Zannettino AC, Paton S, Arthur A, Khor F, Itescu S, Gimble JM, Gronthos S. Multipotential human adipose-derived stromal stem cells exhibit a perivascular phenotype in vitro and in vivo. J Cell Physiol, 2008, 214: 413-421

54 Strem BM, Hicok KC, Zhu M, Wulur I, Alfonso Z, Schreiber RE, Fraser JK, Hedrick MH. Multipotential differentiation of adipose tissue-derived stem cells. Keio J Med, 2005, 54: 132-141

55 Walsh S, Jefferiss C, Stewart K, Jordan GR, Screen J, Beresford JN. Expression of the developmental markers STRO-1 and alkaline phosphatase in cultures of human marrow stromal cells: regulation by fibroblast growth factor (FGF)-2 and relationship to the expression of FGF receptors 1-4. Bone, 2000, 27: 185-195
56 Kim HJ, Im GI. Chondrogenic differentiation of adipose tissuederived mesenchymal stem cells: greater doses of growth factor are necessary. J Orthop Res, 2009, 27: 612-619

57 Lindroos B, Boucher S, Chase L, Kuokkanen H, Huhtala H, Haataja R, Vemuri M, Suuronen R, Miettinen S. Serum-free, xeno-free culture media maintain the proliferation rate and multipotentiality of adipose stem cells in vitro. Cytotherapy, 2009, 11: 958-972

58 Chevallier N, Anagnostou F, Zilber S, Bodivit G, Maurin S, Barrault A, Bierling P, Hernigou P, Layrolle P, Rouard H. Osteoblastic differentiation of human mesenchymal stem cells with platelet lysate. Biomaterials, 2010, 31: 270-278

59 Aggarwal S, Pittenger MF. Human mesenchymal stem cells modulate allogeneic immune cell responses. Blood, 2005, 105: 1815-1822

60 Uccelli A, Moretta L, Pistoia V. Mesenchymal stem cells in health and disease. Nat Rev Immunol, 2008, 8: 726-736

61 Aust L, Devlin B, Foster SJ, Halvorsen YD, Hicok K, du Laney T, Sen A, Willingmyre GD, Gimble JM. Yield of human adipose-derived adult stem cells from liposuction aspirates. Cytotherapy, 2004, 6: 7-14

62 Yanez R, Lamana ML, Garcia-Castro J, Colmenero I, Ramírez M, Bueren JA. Adipose tissue-derived mesenchymal stem cells have in vivo immunosuppressive properties applicable for the control of the graft-versus-host disease. Stem Cells, 2006, 24: 2582-2591

63 Gonzalez-Rey E, Anderson P, Gonzalez MA, Rico L, Büscher D, Delgado M. Human adult stem cells derived from adipose tissue protect against experimental colitis and sepsis. Gut, 2009, 58: 929-939

64 Saka Y, Furuhashi K, Katsuno T, Kim H, Ozaki T, Iwasaki K, Haneda M, Sato W, Tsuboi N, Ito Y, Matsuo S, Kobayashi T, Maruyama S. Adipose-derived stromal cells cultured in a low-serum medium, but not bone marrow-derived stromal cells, impede xenoantibody production. Xenotransplantation, 2011, 18: 196-208

65 Murphy JM, Dixon K, Beck S, Fabian D, Feldman A, Barry F. Reduced chondrogenic and adipogenic activity of mesenchymal stem cells from patients with advanced osteoarthritis. Arthritis Rheum, 2002, 46: 704-713

66 Im GI, Jung NH, Tae SK. Chondrogenic differentiation of mesenchymal stem cells isolated from patients in late adulthood: the optimal conditions of growth factors. Tissue Eng, 2006, 12: 527-536

67 Scharstuhl A, Schewe B, Benz K, Gaissmaier C, Bühring HJ, Stoop $\mathrm{R}$. Chondrogenic potential of human adult mesenchymal stem cells is independent of age or osteoarthritis etiology. Stem Cells, 2007, 25: 3244-3251

68 De Bari C, Dell'Accio F, Luyten FP. Human periosteum-derived cells maintain phenotypic stability and chondrogenic potential throughout expansion regardless of donor age. Arthritis Rheum, 2001, 44: 85-95

69 Jones E, English A, Churchman SM, Kouroupis D, Boxall SA, Kinsey S, Giannoudis PG, Emery P, McGonagle D. Large-scale extraction and characterization of $\mathrm{CD} 271^{+}$multipotential stromal cells from trabecular bone in health and osteoarthritis: implications for bone regeneration strategies based on uncultured or minimally cultured multipotential stromal cells. Arthritis Rheum, 2010, 62: 1944-1954

70 Sekiya I, Ojima M, Suzuki S, Yamaga M, Horie M, Koga H, Tsuji K, Miyaguchi K, Ogishima S, Tanaka H, Muneta T. Human mesenchymal stem cells in synovial fluid increase in the knee with degenerated cartilage and osteoarthritis. J Orthop Res, 2012, 30: 943-949

71 Sakaguchi Y, Sekiya I, Yagishita K, Muneta T. Comparison of human stem cells derived from various mesenchymal tissues: superiority of synovium as a cell source. Arthritis Rheum, 2005, 52: 2521-2529

72 Lee KB, Hui JH, Song IC, Ardany L, Lee EH. Injectable mesenchymal stem cell therapy for large cartilage defects-a porcine model. Stem Cells, 2007, 25: 2964-2971

73 Grigolo B, Lisignoli G, Desando G, Cavallo C, Marconi E, Tschon M, Giavaresi G, Fini M, Giardino R, Facchini A. Osteoarthritis treated with mesenchymal stem cells on hyaluronan-based scaffold in rabbit. Tissue Eng Part C Methods, 2009, 15: 647-658

74 Horie M, Sekiya I, Muneta T, Ichinose S, Matsumoto K, Saito H, Murakami T, Kobayashi E. Intra-articular injected synovial stem cells differentiate into meniscal cells directly and promote meniscal 
regeneration without mobilization to distant organs in rat massive meniscal defect. Stem Cells, 2009, 27: 878-887

75 Sato M, Uchida K, Nakajima H, Miyazaki T, Guerrero AR, Watanabe S, Roberts S, Baba H. Direct transplantation of mesenchymal stem cells into the knee joints of hartley strain guinea pigs with spontaneous osteoarthritis. Arthritis Res Ther, 2012, 14: R31

76 Wong KL, Lee KB, Tai BC, Law P, Lee EH, Hui JH. Injectable cultured bone marrow-derived mesenchymal stem cells in varus knees with cartilage defects undergoing high tibial osteotomy: a prospective, randomized controlled clinical trial with 2 years' follow-up. Arthroscopy, 2013, 29: 2020-2028

77 Orozco L, Munar A, Soler R, Alberca M, Soler F, Huguet M, Sentís J, Sánchez A, García-Sancho J. Treatment of knee osteoarthritis with autologous mesenchymal stem cells: a pilot study. Transplantation, 2013, 95: 1535-1541

78 Ayral X, Pickering EH, Woodworth TG, Mackillop N, Dougados M. Synovitis: a potential predictive factor of structural progression of medial tibiofemoral knee osteoarthritis - results of a 1 year longitudinal arthroscopic study in 422 patients. Osteoarthr Cartilage, 2005, 13: 361-367

79 ter Huurne M, Schelbergen R, Blattes R, Blom A, de Munter W, Grevers LC, Jeanson J, Noël D, Casteilla L, Jorgensen C, van den Berg W, van Lent PL. Antiinflammatory and chondroprotective effects of intraarticular injection of adipose-derived stem cells in experimental osteoarthritis. Arthritis Rheum, 2012, 64: 3604-3613

80 Benito MJ, Veale DJ, FitzGerald O, van den Berg WB, Bresnihan B. Synovial tissue inflammation in early and late osteoarthritis. Ann Rheum Dis, 2005, 64: 1263-1267

81 Loeser RF. The effects of aging on the development of osteoarthritis. HSS J, 2012, 8: 18-19

82 Goldring MB, Marcu KB. Cartilage homeostasis in health and rheumatic diseases. Arthritis Res Ther, 2009, 11: 224

83 Troeberg L, Nagase H. Proteases involved in cartilage matrix degradation in osteoarthritis. Biochim Biophys Acta, 2012, 1824: 133-145

84 Glasson SS, Askew R, Sheppard B, Carito B, Blanchet T, Ma HL, Flannery CR, Peluso D, Kanki K, Yang Z, Majumdar MK, Morris EA. Deletion of active ADAMTS5 prevents cartilage degradation in a murine model of osteoarthritis. Nature, 2005, 434: 644-648

85 Little CB, Barai A, Burkhardt D, Smith SM, Fosang AJ, Werb Z, Shah M, Thompson EW. Matrix metalloproteinase 13-deficient mice are resistant to osteoarthritic cartilage erosion but not chondrocyte hypertrophy or osteophyte development. Arthritis Rheum, 2009, 60: 3723-3733

86 Lories RJ, Peeters J, Bakker A, Tylzanowski P, Derese I, Schrooten J, Thomas JT, Luyten FP. Articular cartilage and biomechanical properties of the long bones in frzb-knockout mice. Arthritis Rheum, 2007, 56: 4095-4103

87 Oh H, Chun CH, Chun JS. Dkk-1 expression in chondrocytes inhibits experimental osteoarthritic cartilage destruction in mice. Arthritis Rheum, 2012, 64: 2568-2578

88 Ma B, van Blitterswijk CA, Karperien M. A Wnt/beta-catenin negative feedback loop inhibits interleukin-1-induced matrix metalloproteinase expression in human articular chondrocytes. Arthritis Rheum, 2012, 64: 2589-2600

89 Chan BY, Fuller ES, Russell AK, Smith SM, Smith MM, Jackson MT, Cake MA, Read RA, Bateman JF, Sambrook PN, Little CB. Increased chondrocyte sclerostin may protect against cartilage degrada- tion in osteoarthritis. Osteoarthr Cartilage, 2011, 19: 874-885

90 Papathanasiou I, Malizos KN, Tsezou A. Bone morphogenetic protein-2-induced Wnt/beta-catenin signaling pathway activation through enhanced low-density-lipoprotein receptor-related protein 5 catabolic activity contributes to hypertrophy in osteoarthritic chondrocytes. Arthritis Res Ther, 2012, 14: R82

91 Prasadam I, Friis T, Shi W, van Gennip S, Crawford R, Xiao Y. Osteoarthritic cartilage chondrocytes alter subchondral bone osteoblast differentiation via MAPK signalling pathway involving ERK1/2. Bone, 2010, 46: 226-235

92 Prasadam I, van Gennip S, Friis T, Shi W, Crawford R, Xiao Y. ERK-1/2 and p38 in the regulation of hypertrophic changes of normal articular cartilage chondrocytes induced by osteoarthritic subchondral osteoblasts. Arthritis Rheum, 2010, 62: 1349-1360

93 Horie M, Choi H, Lee RH, Reger RL, Ylostalo J, Muneta T, Sekiya I, Prockop DJ. Intra-articular injection of human mesenchymal stem cells (MSCs) promote rat meniscal regeneration by being activated to express indian hedgehog that enhances expression of type II collagen. Osteoarthr Cartilage, 2012, 20: 1197-1207

94 Hiraoka K, Grogan S, Olee T, Lotz M. Mesenchymal progenitor cells in adult human articular cartilage. Biorheology, 2006, 43: 447-454

95 Clark AL, Votta BJ, Kumar S, Liedtke W, Guilak F. Chondroprotective role of the osmotically sensitive ion channel transient receptor potential vanilloid 4: age- and sex-dependent progression of osteoarthritis in Trpv4-deficient mice. Arthritis Rheum, 2010, 62: 2973-2983

96 O'Conor CJ, Griffin TM, Liedtke W, Guilak F. Increased susceptibility of Trpv4-deficient mice to obesity and obesity-induced osteoarthritis with very high-fat diet. Ann Rheum Dis, 2013, 72: 300-304

97 Desando G, Cavallo C, Sartoni F, Martini L, Parrilli A, Veronesi F, Fini M, Giardino R, Facchini A, Grigolo B. Intra-articular delivery of adipose derived stromal cells attenuates osteoarthritis progression in an experimental rabbit model. Arthritis Res Ther, 2013, 15: R22

98 Lee KB, Hui JH, Song IC, Ardany L, Lee EH. Injectable mesenchymal stem cell therapy for large cartilage defects - a porcine model. Stem Cells, 2007, 25: 2964-2971

99 Koga H, Shimaya M, Muneta T, Nimura A, Morito T, Hayashi M, Suzuki S, Ju YJ, Mochizuki T, Sekiya I. Local adherent technique for transplanting mesenchymal stem cells as a potential treatment of cartilage defect. Arthritis Res Ther, 2008, 10: R84

100 Guo X, Park H, Young S, Kretlow JD, van den Beucken JJ, Baggett LS, Tabata Y, Kasper FK, Mikos AG, Jansen JA. Repair of osteochondral defects with biodegradable hydrogel composites encapsulating marrow mesenchymal stem cells in a rabbit model. Acta Biomater, 2010, 6: 39-47

101 Centeno CJ, Busse D, Kisiday J, Keohan C, Freeman M, Karli D. Regeneration of meniscus cartilage in a knee treated with percutaneously implanted autologous mesenchymal stem cells. Med Hypotheses, 2008, 71: 900-908

102 Varma HS, Dadarya B, Vidyarthi A. The new avenues in the management of osteo-arthritis of knee--stem cells. J Indian Med Assoc, 2010, 108: 583-585

103 Davatchi F, Abdollahi B S, Mohyeddin M, Shahram F, Nikbin B. Mesenchymal stem cell therapy for knee osteoarthritis. Preliminary report of four patients. Int J Rheum Dis, 2011, 14: 211-215

104 Koh YG, Choi YJ. Infrapatellar fat pad-derived mesenchymal stem cell therapy for knee osteoarthritis. The Knee, 2012, 19: 902-907

Open Access This article is distributed under the terms of the Creative Commons Attribution License which permits any use, distribution, and reproduction in any medium, provided the original author(s) and source are credited. 